\title{
ANTONIO J. WARING, JR., 1915-1964
}

\section{STEPHEN WILLIAMS}

$T$ HE STUDY of Southeastern prehistory has been enriched since its inception by the contributions of persons not professionally trained as archaeologists: Jeffries Wyman was a zoologist; C. C. Jones had a Harvard law degree; and Clarence B. Moore was a dilettante scholar, an "amateur" in the best sense of the word. Antonio J. Waring, Jr., became an archaeologist despite his training as a physician. Although best known for his classic work with Preston Holder (1945) on the chronologically late Southeastern Ceremonial complex (often called the "Southern Cult"), "Tono" Waring made useful contributions to Georgia archaeology of all time periods: Paleo-Indian (1961), Early Pottery (1939b), Hopewellian (1945c), and Historic (1960).

Waring was born on August 17, 1915, the son of Dr. Antonio Johnston Waring and Sue Cole Winburn of Savannah, Georgia. He was a lifelong resident of that historic city. Those orderly, sun-drenched squares and the elegant Oglethorpe Club, from which he irregularly corresponded with his colleagues in his crabbed hand about new discoveries on the Georgia coast, have lost some of their ties to an ancient past with his death on March 21, 1964, after a long battle with cancer.

He was educated in Savannah and at the St. Alban's School in Washington, D.C. His undergraduate training was at Yale University where he majored in English and received the B.A. degree in 1938. He continued at Yale for an M.D., which he received in 1942, and did his internship and residency at Johns Hopkins Hospital in Baltimore. During World War II, he served in the U.S. Army and attained the rank of captain in the Medical Corps with a tour of duty in Egypt. After the war, he practiced pediatrics in Savannah until 1962, when his deep interest in archaeology prompted his retirement from medicine. He is survived by his wife, Henrietta Callaway Waring, his son Brandon, and his mother, sister, and brother.

Waring's interest in archaeology began early and remained a consuming preoccupation for the rest of his life. His first "excavations" were as a boy of 13 at the Indian King's Tomb, an Irene-period burial mound within the city limits of Savannah. At Yale he spent much time studying the collections in the Peabody Museum. He made the acquaintance of George C. Vaillant and during this period visited New York frequently to view the important Spiro collections that were coming into the Heye Foundation.

Georgia archaeology was having a revival in the late 1930's with the Works Progress Administration excavations at Macon under A. R. Kelly. At this time, Waring met and made lifelong friendships with a number of young archaeologists, including Gordon R. Willey, James A. Ford, Joseph R. Caldwell, and Preston Holder, who were engaged in revitalizing Southeastern archaeology. With encouragement and instruction from Holder, he undertook controlled stratigraphic excavations at the Deptford type site in 1937 (MS.b). He carried out more extensive work at the Bilbo site (MS.c) in 1939 with WPA aid. In 1947 he dug at the Refuge site, located just across the Savannah River in South Carolina. The results of these stratigraphic tests have provided a firm sequence of the early pottery horizons on the Georgia Coast (MS.e).

Besides his own work at the sites mentioned above, he assisted many archaeologists in their field research throughout Georgia during his vacations, beginning with summer work on the mortuary structure at the Irene site in 1938 and 1939 under Joe Caldwell's direction. He made lengthy postwar visits to William Sears's excavation at Kolomoki and aided Lewis $\mathrm{H}$. Larson in his work at Etowah. During the last 15 years of his life, Waring did research on the "shell rings" of Sapelo and the adjacent coastal islands, and collaborated with Larson and the University of Georgia in excavations on these interesting fiber-tempered, pottery-horizon sites.

His only truly professional employment, save for the summer work under Works Progress Administration auspices in the late 1930's, came after his retirement from the field of medicine in 1962. During the spring and summer of that year, he was field assistant to Robert S. Neitzel at the Fatherland site near Natchez, Mississippi. Later he was employed by the Georgia Historical Commission to do research and exhibit preparation at "White House" near Augusta, and he 


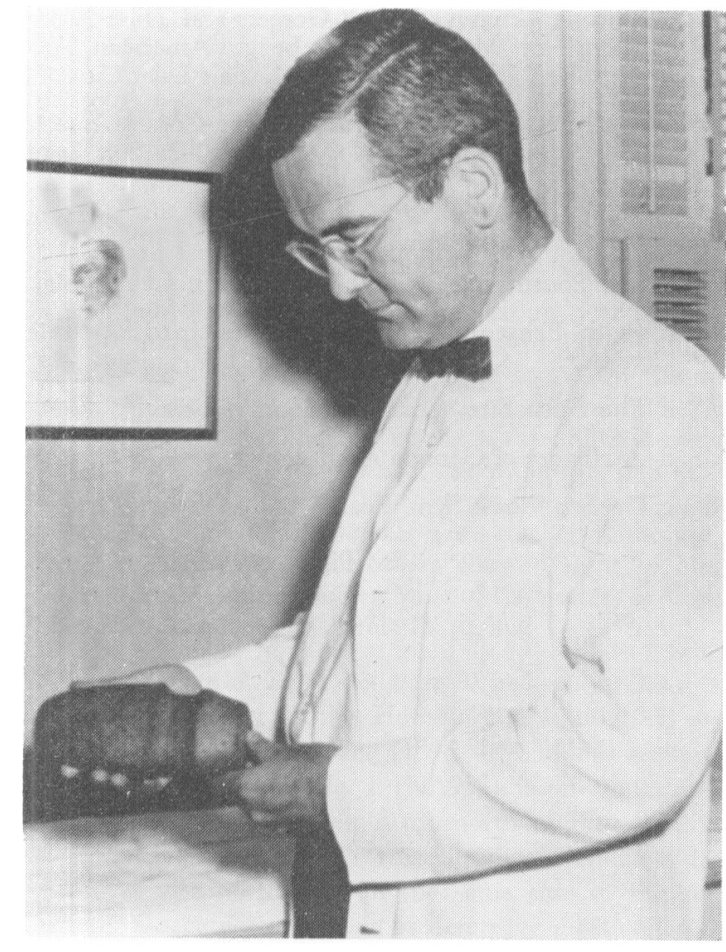

Antonio J. Waring, JR.

was working on the Civil War site of Fort McAllister near Richmond Hill just prior to his death.

The annual meetings of the Southeastern Archaeological Conference provided Waring with ample opportunity to exchange his local information with professional colleagues who were working in the more distant parts of the area. This Conference will certainly be less challenging with the absence of one of its most faithful members, whose incisive comments either from the floor or in postmeeting confrontation kept the group on its toes. He was a regular contributor to the Conference program on topics ranging from De Soto to late Archaic sites.

His professional associations extended to the Bureau of American Ethnology, where he was named a "Collaborator," and his correspondents ranged from William S. Webb of Kentucky to Alex D. Krieger, then at Texas, and to Clarence H. Webb of Louisiana. But he somehow failed to publish many of the manuscripts which he had completed (see Bibliography). Scarcity of publication funds in the 1940's undoubtedly held back the Bilbo report (MS.c). It is planned that many of these works will be made available in permanent form as a fitting tribute to Tono Waring's dedicated interest in the archaeology of the Georgia coast.

Waring was deeply involved in the region and its archaeology, but this did not keep him from tackling broader problems. In the main this interest focused on two topics: the late Archaic culture of the Southeast, often associated with fiber-tempered pottery, and the rich ceremonialism of the late prehistoric cultures connected with the "Southern Cult." Here, as in many things, his interest in complex aesthetics and ritual art contrasted with his urge to know more about some of the earliest potteryusing cultures in North America whose highest artistic expression was to be found in carved bone pins.

Tono was a founding father (with Preston Holder) of the Southeastern Ceremonial complex, nicknamed the "Buzzard Cult" or "Southern Cult" (Waring 1945b). The stimulus of this idea formed a background for many papers in the early postwar period (Waring 1948). His own study (MS.a) on the connection of this ceremonialism with historic tribes was written shortly after the first "Cult" paper, but unfortunately it was never published.

In writing this note, I feel that I have, as one must perforce and perhaps properly do, written much of what he did but little of what he was. $\mathrm{He}$ made scientific contributions to medicine and was respected and loved by a generation or two of Savannah children to whom he ministered. His literary interests nurtured in college days included the writing of a considerable amount of locally published poetry. Tono was thus a man of many and varied talents, and that archaeology received something of great value from his devoted interests cannot be denied: One can only wish that he could have had more time for it.

Bibliography of Antonio J. Waring, Jr.

1939a (With Joseph R. Caldwell) The Use of a Ceramic Sequence in the Classification of Aboriginal Sites in Chatham County, Georgia (abstract). Southeastern Archaeological Conference Newsletter, Vol. 2, No. 1, pp. 6-7. Birmingham.

1939b Fiber-tempered Wares on the Georgia Coast. Southeastern Archaeological Conference Newsletter, Vol. 2, No. 1, pp. 7-8. Birmingham.

1945a (with Preston Holder) A Prehistoric Ceremonial Complex in the Southeastern United States. American Anthropologist, Vol. 47, No. 1, pp. 1-34. Menasha. 
1945b The De Luna Expedition and Southeastern Ceremonial. American Antiquity, Vol. 11, No. 2, pp. 119-20. Menasha.

1945c "Hopewellian" Elements in Northern Georgia. American Antiquity, Vol. 11, No. 2, pp. 119-20. Menasha.

1948a Brief of Symposium on the "Southern Cult." American Antiquity, Vol. 14, No. 2, pp. 151-3. Menasha.

1948b Catalogue of the "Southern Cult." Department of Anthropology, University of Georgia, Athens, Georgia. $4 \mathrm{pp}$.

1959 Review: "The Archaeology of Coastal North Carolina," by William G. Haag. American Antiquity, Vol. 24, No. 4, p. 449. Salt Lake City.

1960a Editor, "Laws of the Creek Nation." University of Georgia Libraries, Miscellanea Publications, No. 1. Athens. 1960b Review: "Engraved Shell Gorgets and Their Associations," by Madeline Kneberg. American Antiquity, Vol. 25, No. 4, pp. 620-1. Salt Lake City.

1961 Fluted Points on the South Carolina Coast. American Antiquity, Vol. 26, No. 4, pp. 550-2. Salt Lake City.

\section{Unpublished Manuscripts}

MS. a The Southern Cult and Muskhogean Ceremonial.

MS.b (with Preston Holder) The Deptford Ceramic Complex.

MS. $c$ The Bilbo Site, Chatham County, Georgia.

MS. d A History of Georgia Archaeology.

MS. e Georgia Coast Synthesis.

Peabody Museum

Cambridge, Massachusetts

October, 1965 